\title{
The Use of Colloquial Words in Improving Students' Speaking Through Teacher's Daily Assessment
}

\author{
Dhia Hasanah \\ Universitas Pendidikan Indonesia \\ Bandung, Indonesia \\ dhiahasanah@upi.edu
}

\begin{abstract}
Recently, there are many ways to get a new vocabulary and to learn English. One of the ways is watching YouTube. Watching Youtube has paid fully attention in students' area. Imitating what favorite YouTubers say in their channel as colloquial words is very common to see in students' daily conversation. The research aims to analyze whether colloquial words can help students to improve their speaking skill in context of communication and how colloquial words help students to improve their speaking skill based on teacher's assessment in daily classroom activity. The participants of this study were eleventh grade students and also an English teacher in one senior high school in Bandar Lampung. This research used qualitative method by having class observation, interview, and rubric analysis. The function of interview was to strengthen the result of observation. In interview section, the researcher asked the teacher about their perspective related to the use colloquial words through students' speaking. Teacher was also asked about their experience in assessing students during classroom activity. The result of this research gave a positive point about how colloquial words could improve students' speaking skill. Teachers believed using colloquial words were able to improve students' vocabulary and also to increase students' confidence in speaking field based on their assessment. Based on this study, researcher suggested teacher to let students using their language styles in speaking.
\end{abstract}

Keywords: colloquial words, speaking skill, teacher's assessment

\section{INTRODUCTION}

Having communication in English is being commonly used for everyone. English has already become individual needs especially in facing global community of the fourth industrial revolution. It makes English becoming one of the important subjects in school. As millennial generation, students have to master both written and spoken skill of English. Lindsay and Knight (2006) have clearly stated that speaking is as productive skill that involves putting a message together, communicating the message, and interacting with other people. Speaking is one of the main skills which has an important role in learning English. Being good at speaking English makes students more ready to start a communication with others and get involved in the new globalization. Oradee (2012) states that in foreign language teaching and learning, the ability to speak is the most essential skill since it is the basic for communication. Therefore, speaking skill is the important skill to be learnt in foreign language learning as the bridge of communication.

However, the use of any language in communication gets modified by the time relates to a social phenomenon. It makes a changing of language itself that is generally divided into two. Standard English is usually used in formal style of speech and also used in formal event. In non-standard English has an informal style of speech. An informal style of speech often sees in colloquial, which may be a single word or a group of words.

Colloquial is included in informal English. The literal meaning of colloquial according to the Oxford (2010) dictionary is 'a word and language used in conversation but informal speech or writing'. According to the Cambridge (2005) dictionary colloquial is 'an informal word or expression which is more suitable for using it in speech than in writing'. Then, based on Merriam Webster (2006) dictionary colloquial is 'used when people are speaking in an informal way or style'. From those three dictionaries that are used can conclude about colloquial as the variety of informal language in conversation or other communication.

Colloquial speech refers to the total set of utterances in a familiar, informal context such as at home, at a place of relaxation or at the workplace (Epoge, 2012). It means that informal English is called colloquialism since it is often used in daily communication. For example: when people are talking to person who has close relationship such as family or friends.

Today electronic communication has resulted in serious grammatical and spelling errors which have changed the language of students' assignments from formal to informal (Barseghyan, 2013). There have been many studies conducted that are related to social media and colloquial words. The first one comes from Trimastuti (2017) who analyzes slang words on social media. In this study, the author shows the impact of social media through students' writing such as 
WhatsApp, Twitter, Instagram, Line, Facebook and etc. The result of study shows teenagers use slang or colloquial words only in their circle.

The updated previous study comes from Hasmi, Mahmood, and Naz (2019), the study they conducted is titled "Impact of Mass Media in the Use of English Slang Words/Short Forms among Pakistani Students". In their study, it investigates the influence of slang words in Pakistani context, where students have started using the slangs/short forms in their academic writing. This study also explains how to develop students' writing by using slang words form through mass media.

Nowadays, the impact of that case is using of colloquial words is getting more and more popular in social media especially on YouTube. Mostly public figures use colloquial expression on their YouTube channel making their content more interesting. Based on this case, students like imitating what their public figures say and it becomes a trend in society. It is possible to make students bring the colloquial words in context of daily communication or classroom activity.

In line with the explanation above, this study is going to analyze whether colloquial words can help students to improve their speaking skill in context of communication and how colloquial words help students to improve their speaking skill based on teacher's assessment in classroom activity. The findings of the study are expected to be one of the references for teachers letting students to use their language style in speaking.

This scope of the research is limited to be included only the use of colloquial words through students' speaking skill. This research focuses on investigating the use of colloquial words can improve students' speaking skill. The participants of this study are the students of senior high school and an English teacher in Bandar Lampung. The reason why the researcher chooses senior high school students because they are good at speaking and having broad knowledge and the researcher chooses an English teacher because teacher can give deeper information based on their perspective about the phenomenon of colloquial words during teaching.

The current study is significant in exploring the use of colloquial words in improving students' speaking skill. There are various studies concerning about the colloquial words that had been conducted in Indonesia and in other countries. These are several studies in line with the case of this study. The first one is from Amir and Azisah (2017). They conduct the research about gender analysis on slang language in students' daily conversation. In this study, they categories the use of slang words between male and female. Based on the result of the research, male has higher percentage than female. It means that male and female students use slang language in different way and also frequency.
From previous year, Muhartoyo and Wijaya (2014) also make a research about colloquial words. The purposes of their study are to point out the reason why students like using English slang, how students acquire English slang, and what kind of slang that students mostly use. Through their study, they analyze the answers of respondents that more than half of the respondents say that the reason why students use slang words is to minimize the time when talking, texting, or tweeting.

In relation to this study that discusses about colloquial words in daily context of classroom activity happens recently. Epoge (2012) reveals that colloquial refers to the total set of utterances in a familiar, informal context such as at home, at a place or relaxation or at workplace. This informal type of speech is used among friends and other in situation where can be expressed in daily context. Further explanation McCrimmon (1963: 143) describes colloquial English as relatively short simple sentences, often grammatically incomplete, with few rhetorical devices.

According to Partridge (in The Encyclopedia Americana, 1990), colloquialism may consist of five types. They are in the form of:

1. Single word

Single word usually uses in daily speech as an informal word. To know whether a single word is colloquial expression it is checked in Spears' NTC's Dictionary of American Slang and Colloquial Expressions (2000). The examples chill, nasty, and dude.

2. Clipped words

Clipped word is a new word which formed by shortening the original word. The original word is shortened by omitting one syllable or more, for example the word phone, bike and exam.

3. Short picturesque words for technical terms

It is a short and picturesque word which is used as a variation to call another technical term as imagery, such as bugs and flowers.

4. Contractions

Contraction is shortened form of one or two words by omitting internal letter. Some examples are "we'll" or "can't".

5. Verb-adverb combinations (compound word)

This combination consists of verbal followed by adverb, such as put out.

\section{METHOD}

In conducting the research, a descriptive qualitative method was chosen to conduct this research since the method was suitable to give a description of analysis data. As stated by Creswell (2008), "descriptive qualitative study aims to investigate detail 
rendering of people, places, or events in a setting in qualitative approach". This study was conducted in one of senior high school in Bandar Lampung. Qualitative research puts emphasis on the qualities of entities and on processes and meanings that are not experimentally examined or measured in terms of quantity, amount, intensity, or frequency. As it was stated by Creswell (2008) that qualitative research is sites that could help the researcher to understand certain phenomenon.

This study was conducted at one of the senior high school in Bandar Lampung. This research was taken one class that consisted of 31 students. The participants of this study were eleventh grade students and an English teacher who taught in that school for more than a year. The selection of the participant was based on age that teenagers are good at speaking and also having a broad knowledge.

To get a valid data of this study, the researchers used some instruments that were observation and interview. The instruments were used to answer the research questions in this study. The first session is held in the classroom by observing students while they have learning process. The purpose of observation is to know the atmosphere in the class and also to get a general comprehensive about classroom activity. The researcher fully observed the classroom situation. The researcher found how students communicate with teacher and other students and how students deliver their ideas through their style of language in the classroom. After doing observation, the second session is conducted by having interview. The researcher interviews the teacher who just taught in the class. The function of interview is to strengthen the result of observation about the use of colloquial words through students' speaking. The questions of interview are made based on speaking rubric in order to get a valid data.

Kim (2010) has argued that the assessment of speaking, as an extremely difficult skill to test, involves a number of procedures to capture all the defining characteristics for objectives testing. An understanding of the nature of speaking not only helps define the construct in question, but ultimately makes it possible to identify factors involved in speaking assessment. In other words, assessing speaking does not only do in speaking test but also do in every meeting. The researcher made observation to analyze the nature of students' speaking can be seen in discussion or presentation in the class. In the process of analyzing the result of observation, the researcher synchronized the data of interview.

\section{FINDINGS AND DISCUSSION}

A. Analysis Question Number 1: Can colloquial words help students to improve their speaking skill in context of communication?

The result of having full observation in classroom indicated the number of colloquial words that were used by students in communicating with other students. The main topic of the lesson was about giving suggestions and offers to others that was the $11^{\text {th }}$ grade of senior high school. The researcher started observation of the class from the beginning until the end.

While the class activity was running, the researcher observed the whole situation in the class. The things that the researcher paid attention were the way how the students' style in communication with other friends in the class. The main activity of the meeting, teacher divided students into some groups and asked them to make a role play about giving and responding suggestion and offers.

During teaching and learning activity, colloquial words could be heard in classroom activity. Based on the classifying of colloquial types they are in the form of single words, clipped words, contractions, and verbadverb combinations. Students mostly used contraction and single words in their speaking when they had discussion and present their role play. The colloquial words that students used are described in Table I and II.

\section{TABLE I. CONTRACTION}

\section{Contraction}

\begin{tabular}{|l|l|}
\hline 1. & Yes, that's great idea. \\
\hline 2. & Why don't we go somewhere for holiday? \\
\hline 3. & My family and mewanna go to Jakarta. \\
\hline 4. & I'd be happy if we can go to hospital together. \\
\hline 5. & I'm fine, thanks. And you? \\
\hline 6. & How's your life? \\
\hline 7. & I couldn't be more happy to go to Japan. \\
\hline 8. & We're gonna meet you there. See ya. \\
\hline 9. & Lemme do it. Gini aja \\
\hline
\end{tabular}

TABLE II. SINGLE WORD

Single Word

\begin{tabular}{|l|l|}
\hline 1. & Hi guys! \\
\hline 2. & Don't get nervous, chillaja. \\
\hline 3. & It will be freak. \\
\hline
\end{tabular}

Through the data result, the researcher figured out that some students mostly showed contraction colloquial words in their speaking. The colloquial words that students used were common expression in daily conversation. The analysis of 1st question based on Table I and II showed the numbers of colloquial words that they used in communication. The numbers pointed that there was an impact of using colloquial words in students' speaking.

Based on the result of observation, the researcher also found the use of colloquial words in shortening the 
words to make simply pronunciation. Furthermore, Dansieh (2011) discussed the other school of thought as well who consider the use of slang words as a blessing as it enhances student's communication skills. Students used colloquial to make them easier to speak. It meant that the colloquial words could help students to improve their speaking skill.

\section{B. Analysis Question Number 2: How do colloquial} words help students to improve their speaking skill based on teacher's assessment in daily classroom activity?

Findings some sources related to speaking assessment had done to do before the researcher made some questions for interview. In making questions, the researcher used two references of speaking rubrics. They were from NTCE (2013) and speaking rubric modified by the teacher as shown in Figure 1.

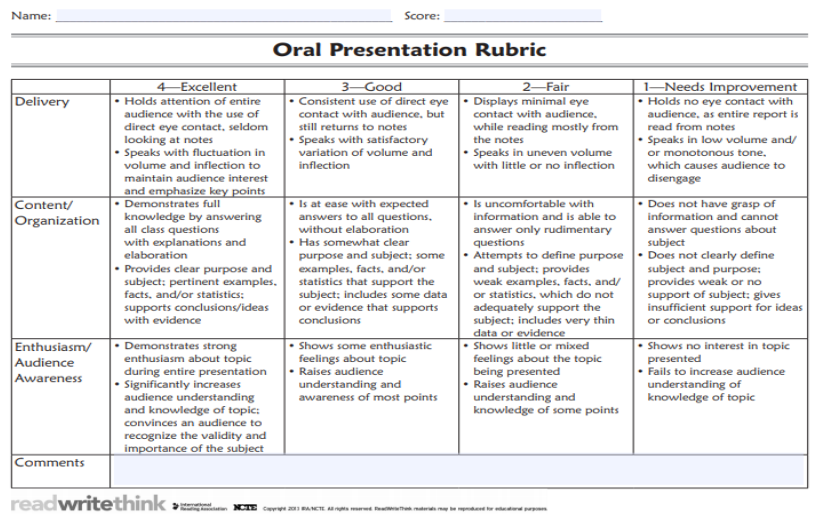

Fig. 1. NTCE's speaking rubric

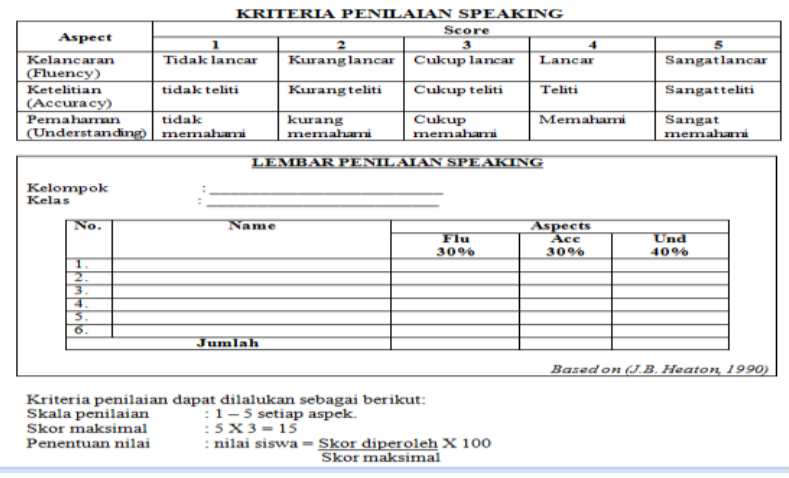

Fig. 2. Teacher's speaking rubric

As shown in Figure 2, There are some points that are considered to give students' speaking score according to NTCE's speaking rubric-delivery, content/organization, enthusiasm/audience awareness and comments from teacher. The scales of scoring in NTCE's speaking rubric are $1-4$ that are indicating to need improvement to excellent. On other hand, a teacher's speaking rubric in Table IV is based on the teacher. The researcher asked the validity of the scoring form to the teacher. The teacher said that speaking rubric was based on the general speaking criteria of curriculum. The teacher just adjusted some points so that students could achieve the criteria of speaking. There are some points that are considered to give students' speaking score according to teacher's speaking rubric - Fluency, accuracy and understanding.

Based on two criteria rubrics above, the researcher concluded some points to be asked. The questions were about:

1. Teacher's opinion about colloquial words.

2. Teacher's opinion about the role of colloquial words can improve students' pronunciation.

3. Teacher's opinion about the use of colloquial words can improve students' vocabulary.

4. Teacher's opinion about the use of colloquial words can help students to elaborate their idea.

After observing the class, the researcher had interview with the teacher based on the guidance of questions that showed above. The teacher explained why this rubric was selected to be the current rubric in scoring the students' achievement. This scoring form was suitable for students in this school. The teacher also explained why she did not put grammar as the criteria. According to the teacher important point of assessing speaking were students' confidence and vocabularies.

During the interview, the teacher gave positive answers related to the questions. She said that she knew about the phenomenon of colloquial words in social media. She also gave a positive perspective about colloquial words through students' speaking skill. According to the result of interview, students were more confident in speaking and sometimes students acted their pronunciation as if they were native. Teacher also found new vocabularies from students in every meeting. The vocabularies that they used to communicate were got from social media.

The phenomenon of colloquial words made students imitating what other people said. Not only from social media, movie, song or society could be included as sources for students to get new vocabularies. When students got new vocabularies, they would found the words in dictionary and after that students would practice it in society. On the other side, teacher explained that colloquial words could not help students to elaborate their ideas because not all colloquial words could be used in some context. Mostly students used repetition and got a trap in a word that they did not know the meaning. Students still the lack of vocabularies in some cases.

\section{CONCLUSION}

In line with the research question of this study, it is to investigate how colloquial words help students to 
improve their speaking skill. As it is revealed based on the data given, it is demonstrated that the phenomenon of colloquial words is significantly given a positive performance in term of students' pronunciation and vocabulary. Based on the observation in the classroom and interview with the teacher, the researcher would like to point out some conclusions.

The first conclusion that is taken from the data result from in this research that colloquial words help students in speaking skill. Most of students show if they enjoy speaking with colloquial words. The second conclusion is based on teacher's daily assessment that shows positive and negative about the use of colloquial words. It was clearly showed in the result of observation and interview that students were more confident in pronouncing colloquial words.

To sum up the results above, it has been found the positive of using colloquial words in students' daily communication in classroom. A teacher believed that using colloquial words make students easier to communicate in order to avoid the complex vocabulary and compact patterns of English language. Furthermore, the using of mobile phones had also a very strong effect on the students' use of colloquial words. The habit of watching and listening kind of social medias have affected the students' speaking because they used short and ungrammatical structures while communication. Through this research, the researcher found the increasing of students' fluency, vocabulary and confidence in speaking by teacher's assessment.

Through this research, the researcher also found the positive and negative effect of colloquial words. For the betterment of teaching and learning process development research in the future, there are some recommendations initiated by the researcher of this study.

1. It is suggested to students to pay more careful in using of negative colloquial words that was used to show anger and bad emotion. It was not good to be imitated.

2. It is suggested to parents to counsel and monitor the students' activities on social media.

3. It is suggested to a teacher to give a guidance explanation about the meaning of bad colloquial words but not to give limitation for students in delivering their ideas. A teacher should let students use their style in speaking.

\section{REFERENCES}

Amir, K., \& Azisah, S. (2017). Gender analysis on slang language in students' daily conversation. English, Teaching, Learning, and Research Journal, 3(2), 229-243. doi: 10.24252/Eternal.V32.2017.A10

Barseghyan, L. (2013). On some aspects of internet slang. Graduate School of Foreign Languages, 14, 19-31.

Cambridge. (2005). Cambridge advanced learner's dictionary. Cambridge University Press: UK.

Creswell, J. W. (2008). Research design: qualitative, quantitative, and mix methods approaches ( $3^{\text {rd }}$ Edn.). Thousand Oaks, California: SAGE Publications, Inc.

Dansieh, S. A. (2011). SMS texting and its potential impacts on students' written communication skills. International Journal of English Linguistics, 1(2), 222-229. doi: 10.5539/ijel.v1n2p222

Epoge, N. K. (2012). Slang and colloquialism in cameroon English verbal discourse. International Journal of Linguistics, 4(1), 130145. doi: $10.5296 /$ ijl.v4i1.1414

Hasmi, M. A., Mahmood, M. I., \& Naz, T. (2019). Impact of mass media in the use of English slang words/short forms among Pakistani students. International Journal Education Science, 24(1-3), 8-12. doi: 10.31901/24566322.2019/24.1-3.1073

Kim, H. J. (2010). Investigating the construct validity of a speaking performance test. Spaan Fellow Working Papers in Second or Foreign Language Assessment, 8, 1-30.

Lindsay, C., \& Knight, P. (2006). Learning teaching and english. New York: Oxford University Press.

McCrimmon, J. (1963). Writing with a purpose ( $3^{\text {rd }}$ Edn.). New York: Houghton.

Merriam Webster. (2006). Webster's new explorer encyclopedic dictionary. Federal Street Press: United States of America.

Muhartoyo, M., \& Wijaya, B. S. (2014). The use of English slang words in informal communication among 8th semester students of English Department in Binus University. Humaniora, 5(1), 197-209. doi: 10.21512/humaniora.v5i1.3009

NTCE. (2013). Oral presentation rubric 3-12. Newark, DE: IRA. Available at: www.readwritething.org/classroomresources/printouts/oralpresentation-rubric-30700.html.

Oradee, T. (2012). Developing speaking skills using three communicative activities (Discussion, problem-solving, and role-playing). International Journal of Social Science and Humanity, 2(6), 533-535.

Oxford. (2010). Oxford advanced learner's dictionary. Oxford University Press: New York.

Spears, R. A. (2000). NTC's dictionary of American slang and colloquial expressions $\left(3^{\text {rd }} \mathrm{Edn}\right.$.). The McGraw-Hill Companies: United States.

Trimastuti, W. (2017). An analysis of slang words used in social media. Jurnal Dimensi Pendidikan dan Pembelajaran, 5(2), 64-68. doi: 10.24269/dpp.v5i2.497

Partridge, E. (1990). Colloquialisms in the encyclopedia Americana. USA: Grolier Incorporated. 